\title{
The Impact of Import Competition \\ on Japanese Manufacturing Employment
}

\author{
Eiichi Tomiura* \\ Research Institute for Economics and Business Administration, Kobe University, \\ 2-1 Rokko-dai, Kobe City, 657-8501, Japan \\ E-mail: tomiura@rieb.kobe-u.ac.jp
}

April 2001

\begin{abstract}
Although previous studies of the effect of imports on Japanese employment relied on relatively aggregate data, the variability among industries is substantial within each two-digit sector. This paper exploits recently available longitudinal data of 390 manufacturing industries and controls for industry-specific factors at the four-digit level. This paper finds the significant impact of import price changes on Japanese employment. The estimates suggest that substantial share of average employment decline can be accounted for by the intensified import competition and that the employment sensitivity increases with industry import share. All these findings are significant especially for the yen appreciating recession years.
\end{abstract}

Journal of Economic Literature Classification Numbers: F14, F41.

\footnotetext{
* I am grateful to Yukio Uchida for his excellent research assistance. Valuable comments from Naoki Mitani are appreciated. All remaining errors are mine.
} 


\section{INTRODUCTION}

The intensified import competition must have non-negligible impact on many decision variables of domestic firms in increasingly globalized economies. Among the variables of concern, employment is one of the most serious indicators for households and policy makers. Despite the attention to the possibility of deindustrialization in Japan, there has been very little formal research for the effect of foreign trade on Japanese employment. When we limit our scope to papers in international academic journals published during the last decade, Dekle (1998), Rebick (1999) and Tachibanaki et al. (1998) are almost the sole contribution to this issue. ${ }^{1}$ On the other hand, various studies, including Revenga (1992), since Branson and Love (1988), have accumulated for the U.S. case to meet the challenges posed by the appreciating dollar and high unemployment in the 1980s. One of the reasons for this lack of analyses of Japanese experience may have been the relative stability of employment once assured by the Japanese traditional long-term employment practice, but the unemployment has now become a serious economic problem in Japan. Hence, the direct investigation of impact of international competition on Japanese employment is required to respond to the needs both in academia and in policy circles.

Previous studies of Japanese employment and imports, however, have been limited to those using relatively aggregate data, although they succeeded in revealing important regularities. Dekle (1998) found, by estimating the labor demand function, that yen fluctuations have a sizable impact on Japanese employment. By decomposing Japanese demand into

\footnotetext{
${ }^{1}$ Even if we expand our scope to earlier literature on this issue, we can think of no directly relevant papers other than Higuchi (1989) and Brunello (1990). Several authors are interested in the effect of foreign direct investment on employment or the effect of imports on wages in Japan. On the other hand, Burgess and Knetter (1998) accomplish an international comparison of G-7 countries, including Japan, on employment response to exchange rates.
} 
components, Rebick (1999) detected that employment changes of men are strongly related with export growth but import share changes have no noticeable effect on employment changes. Tachibanaki et al. (1998) reported, based on cross-section regressions of Japanese industries, that the relation between employment and imports has generally been weak while the imports from China could have a strong effect on wages. All these findings are very informative, carefully based on analytically elaborated methods and produced critical implications, but, at the same time, are unfortunately constrained by the limitation of Japanese import data concorded to a domestic industry basis. All previous empirical work on Japanese employment and trade, as far as the author knows, relied on broadly defined two-digit data. ${ }^{2}$ This contrasts with studies of the U.S. case since they have already extensively employed four-digit data.

The level of data aggregation is beyond an issue of mere curiosity. As will be explained in this paper, substantial variability is actually observed across four-digit industries within the same two-digit sector in terms of import penetration and of employment growth in the case of Japanese manufacturing. For example, the import share of industries ranges widely from one-hundredth percent up to 98 percent in 1995 if industries are disaggregated into the four-digit level, while the variation is at most around thirty percent among two-digit sectors. Therefore, since the two-digit classification is obviously too broad for our purpose, we need to control for various industry-specific factors at more disaggregated level.

To meet such a requirement, this paper exploits recently available four-digit longitudinal data of 390 Japanese industries, based on the data concordance between import statistics and Japan's Annual Survey of Manufacturers (Kogyou Tokei, in Japanese) established by

\footnotetext{
${ }^{2}$ For example, Rebick (1999) uses observation of 18 two-digit industries with five-year intervals. Tachibanaki et al (1998) also depend on two-digit data of 22 industries, although they are annual. The data set of Dekle (1998) consists of 12 two-digit industries.
} 
Tomiura and Uchida (2001). ${ }^{3}$ The number of industries whose data are available, 390 , is much larger than typical numbers in previous studies; i.e. around twenty. The impact of import competition on employment is examined by estimating the labor demand function in the open economy, as in Dekle (1998). ${ }^{4}$ The instrumental variables are assigned to the wage, the import price and the import share, because they are supposed to be endogenously determined. The sample period in the data set, 1988-1995, is quite information rich, as it covers both the boom years with relatively stable exchange rate and the recession years after the burst of real estate and stock bubble with yen appreciation. ${ }^{5}$ To examine the possible asymmetry in employment response during these years, this paper splits the whole sample period into two sub-periods.

To preview our results, this paper demonstrates, by controlling for the industry-specific effect at the disaggregated level, that Japanese employment is significantly responsive to import price changes and that substantial share of average employment decline can be explained by the intensified import competition. This paper also finds that the employment sensitivity increases with industry import share. All these three principal findings are significant in the years of recession with yen appreciation after 1993.

The remainder of the paper is structured as follows. Section II explains the data concordance and documents the inter-industry variation at the four-digit level. Section III formalizes our econometric specifications. Section IV reports the empirical results. Finally,

\footnotetext{
3 Tomiura and Uchida (2001) describe the data set in detail and apply it to the preliminary study of gross job creation and destruction. Since their gross job flow data are available only twice in five years, this paper is the first attempt to use this concorded data to the analysis of longitudinal data with sufficient observations along the time dimension.

${ }^{4}$ As will be explained, we cannot choose the approach by Rebick (1999) due to the data constraint on the export side. The econometric models in Tachibanaki et al. (1988) are not formalized in an optimization framework. On the other hand, the reduced-form estimation, as in Revenga (1992), is vulnerable to misspecifications of labor supply function.

5 The data before 1988 is not available because the import classification system was substantially changed in that year due to the adoption of the international harmonized system of tariff
} 
Section V concludes.

\section{MATCHING IMPORT AND EMPLOYMENT DATA AT 4-DIGIT LEVEL}

Whenever a researcher becomes interested in the impact of trade on employment and wages, the matching of import data to labor data has always been a substantial problem because two statistics adopt different classification systems in many countries, including Japan and the U.S. Even if we trace import data back to nine-digit levels in the Harmonized System (HS) classification which identifies more than eight thousand products, some products cannot be mapped to one particular domestic industry. ${ }^{6}$

The availability of matched data, however, sharply varies depending on the countries under investigation. For the U.S. case, a comprehensive data concordance has already been established at NBER by Feenstra (1996) and been extensively used by many researchers. ${ }^{7}$ To evaluate the impact of import competition on Japanese employment or wages, on the other hand, each researcher must establish own concordance table from scratch. Hampered mainly by the lack of import data concorded to a domestic industry classification, previous studies of Japanese data have been limited at two-digit sectors (e.g. Higuchi (1989), Brunello (1990), Burgess and Knetter (1998), Deckle (1998), Tachibanaki et.al. (1998), and Rebick (1999)), while U.S. industries have already been often explored at four-digit level (Revenga (1992), for example). As will be explained later, the two-digit level classification is obviously too broad for studying the impact of import on employment since the degree of import penetration substantially varies among four-digit industries even within the same two-digit sector. Unless

\footnotetext{
classifications. The data for 1995 is the most recent one at the time of data concordance research.

${ }^{6}$ For example, many industries are classified in domestic industry classification by their production/processing method, which is unknown for imports produced/processed outside of the country.

${ }^{7}$ The data set constructed by Feenstra (1996) contains U.S. import data with many classifications such as SIC, SITC, and HS.
} 
we trace back at least to four-digit level and control for industry-specific factors, we cannot exclude the possibility that the aggregation effects could contaminate the results previously obtained at two-digit Japanese data.

This paper employs the import and employment data matched by Tomiura and Uchida (2001), which is the most comprehensive data concordance to date for Japanese industries available at the four-digit level. ${ }^{8}$ Since we believe the relation of employment with international competition is a current serious concern, this paper is intended to be an early contribution to the investigation of Japanese employment and import, by using this recently available data. The number of industries of which the data are available in this data set, 390, is by far the larger than those examined previously, i.e. from eight to twenty-four. The data set is also informative in that it includes, instead of a sub-sample of, all manufacturing industries, excluding only non-tradables. ${ }^{9}$ Since the sample period of concorded data is from 1988 to 1995 , we have a longitudinal data of 3120 observations (390 industries for 8 years). The use of this detailed data set must contribute immensely to an understanding of Japanese response of employment to import competition.

Before discussing formal models and estimations, brief overview of basic statistics will be useful. Table I summarizes the import share data classified by two-digit sectors. The import share kept rising in many sectors. What is most striking in Table I, however, is the tremendous heterogeneity across four-digit industries within each two-digit sector. For example, in the

\footnotetext{
${ }^{8}$ For detailed information on this data set, see Tomiura and Uchida (2001). The import data classified according to the domestic industry classification and the complete listing of SIC codes of industries will be downloadable at the web site.

${ }^{9}$ Out of 562, all four-digit domestic industries, 72 industries are excluded as nontradables. The SIC codes for these industries are listed in Tomiura and Uchida (2001). Other 490 industries are aggregated into 390 industries, of which each of 334 industries has one-to-one direct correspondence in import statistics. Although necessary to complete the analysis of impact of international competition, we leave the study of export to future work since no data concordance tables are currently available at a comparably disaggregated level and since we believe import effect can be examined separately from export effect.
} 
electric machinery industry, the largest sector in Japan in terms of employment size, imported products reached in 1995 to occupy nearly eight percent of the domestic market. The variation within the sector, however, is substantial since there simultaneously exist an industry with import share exceeding twenty percent (radio and television sets) and an industry with that less than one-tenth percent (traffic signal control equipment). ${ }^{10}$ Besides, while the highest import share observed at the two-digit level is at most around thirty percent, the same table also shows that imports actually dominate some industries with import share exceeding ninety percent when we disaggregate industries into the four-digit level. We cannot neglect thus considerable inter-industry variation.

Table II documents the basic descriptive statistics of related variables, including employment and wages. The employment expanded in the first sub-period (1988-92) by around one percent and declined by slightly less than three percent during the latter sub-period (1993-95) if we measure the changes as the unweighted average of employment growth rates in 390 industries. The observation of such a mild employment fluctuation, however, should be viewed rather as an artifact of aggregation. The employment in industries with their growth rates one standard deviation above mean increased by more than 26 percent during 1988-92, while industries whose employment change rates lied one standard deviation below average experienced employment shrinkage of nearly twenty percent during 1992-95. Such a large variation in employment growth is a good illustration of substantial inter-industry heterogeneity in many variables. In sum, as the figures in the table do demonstrate such wide variability across industries during the same period, we must control for various industry-specific factors in investigating labor demand.

\footnotetext{
10 The names and SIC codes of the four-digit industries with maximal and minimal import penetration ratio are not shown in the table to save space, but are available upon request by the author.
} 


\section{MODEL AND SPECIFICATION}

This section aims to set out a simple theoretical framework and to discuss the methods for estimation. First, the supply-side of the industry $i(i=1,2, \ldots, N)$ at time $t(t=1,2, \ldots, T)$ can be summarized by the following standard cost function:

$$
C_{i t}=\phi_{i t} w_{i t}^{\gamma_{1}+1} c_{i t}^{\gamma_{2}} Q_{i t}
$$

,where w, c, and Q denote wage, non-labor input costs, and output quantity, respectively. The factor markets are assumed to be perfectly competitive. Other cost shifters are captured by $\phi$. We naturally assume $0<\gamma_{1}+1<1,0<\gamma_{2}<1$. By Shephard's lemma, the labor demand is derived, suppressing the subscripts, as following;

$$
L=\frac{\partial C}{\partial w}=\phi\left(\gamma_{1}+1\right) w^{\gamma_{1}} c^{\gamma_{2}} Q
$$

Next, consider the demand-side of the industry by introducing the following standard demand function for the output:

$$
Q_{i}=A\left(\frac{p_{i}}{e p_{i}^{*}}\right)^{-\theta} y^{\gamma_{3}}
$$

,with $p_{i}, p_{i}^{*}, y$ denoting the price of the $i$ th product which is supplied by the domestic industry, the price of imported i-th product, and domestic income, respectively. All the 
variables except for the import price $\mathrm{p}^{*}$ are denominated in terms of home-country's currency (yen, in the case of Japan), while $\mathrm{p}^{*}$ is expressed in source-country's currency (\$, say). The nominal exchange rate $(¥ / \$$, say) is referred to as $e$. We assume that the product produced in the home country is an imperfect substitute for the imported product. ${ }^{11}$ Other factors shifting demand are expressed by the term A. Both $\theta$ and $\gamma_{3}$ are naturally assumed positive.

By plugging (3) into (2) and by replacing the endogenous own output price, we can derive the following labor demand function in the first-differenced logarithm form:

$$
d \ln L=\delta_{0}+\delta_{1} d \ln w+\delta_{2} d \ln c+\delta_{3} d \ln y+\boldsymbol{\theta} d \ln e p^{*}+\varepsilon
$$

,where $\varepsilon$ denotes the error term with usual properties. The coefficient on wage, $\delta_{1}$, should be negative in the labor demand function. We expect the positive sign for the coefficient on the import price, $\theta$, since the import price fall intensifies competition and thus reduces demand for labor in domestic industries. The estimate of the employment elasticity with respect to the import price, $\theta$, is the main target of this paper.

In addition to (4), the following specification that includes the interactive term of import price with the import share MS will also be estimated

$$
d \ln L=\boldsymbol{\delta}_{0}+\boldsymbol{\delta}_{1} d \ln w+\boldsymbol{\delta}_{2} d \ln c+\boldsymbol{\delta}_{3} d \ln y+\boldsymbol{\theta}_{0} d \ln e p^{*}+\boldsymbol{\theta}_{1} M S d \ln e p^{*}+\varepsilon
$$

\footnotetext{
${ }^{11}$ In evaluating the impact of imports on employment, this paper concentrates on the direct competition between final products which are substitutes. It is true that import penetration also affects employment through imported inputs into production. Analyzing these two effects within the same model, however, is empirically difficult because both are often highly correlated and difficult to distinguish without extensive dependence on input-output tables. Campa and Goldberg (1998) limited themselves to the latter channel, although they distinguish two routes in their theoretical model.
} 
because the sensitivity of employment to imports is likely to vary positively with the industry's exposure to imports. Naturally, we expect $\theta_{1}$ as well as $\theta_{0}$ be positive. Using the estimates, we can calculate the industry-specific employment elasticity of the i-th industry $\theta_{i}$ by $\theta_{i}=\theta_{0}+\theta_{1} M S_{i}$

In estimating the above equations (4) and (5), we will assign instrumental variables (IV) to the wage, to the import price and to the import share because all these variables are supposed to be endogenously determined. ${ }^{12}$ The OLS estimation treating these variables as exogenous will yield biased and inconsistent estimates. We will check this point by comparing the result of IV estimation with that of OLS.

\section{EMPIRICAL RESULTS}

The specifications derived in the previous section are adapted to the following empirical counterpart, taking account of the availability of data and the fitness of the model:

$$
\begin{aligned}
d \ln L_{i t}=\alpha_{i} & +\theta_{0} d \ln P_{i t}^{m}+\theta_{1} M S_{i t} d \ln P_{i t}^{m}+\beta d \ln w_{i t}+\lambda d \ln L_{i, t-1} \\
& +\gamma_{0} d \ln c_{i t}+\gamma_{1} d \ln c_{i, t-1}+\varepsilon_{i t}
\end{aligned}
$$

,where $P^{m}$ denotes the import price in terms of domestic currency, yen. As in Revenga (1992), the import price data employed here are actual transaction prices of importers derived from WPI statistics, instead of the unit value indices. ${ }^{13}$ In calculating the import share, MS, of every

\footnotetext{
${ }^{12}$ Dekle (1998) is the most closely related research with this paper in estimating the labor demand function, since many other previous studies such as Burgess and Knetter (1998) and Revenga (1992) estimated the reduced-form equation derived from interaction with the labor supply function. While he assigns instrumental variables to wage, Dekle (1998) differs from this paper in treating import price and import share as exogenous.

13 The most closely corresponding category in WPI is assigned to each SIC industry. No imputation was used. The concordance table is available upon request by the author.
} 
four-digit industry, this paper utilizes the data concordance by Tomiura and Uchida (2001), which combines import statistics and Annual Survey of Manufacturers. ${ }^{14}$ All other data are consistently drawn from Annual Survey of Manufacturers. ${ }^{15}$ Price series are deflated. ${ }^{16}$ Similarly in Dekle (1998), the lagged employment is introduced to capture the effect of employment adjustment costs. All the variables included in the regression (6) are industry-specific. ${ }^{17}$ The industry-specific dummy variables, $\alpha_{i}$, are included, while the year-specific dummies are omitted just to improve the fitness. ${ }^{18}$ Let us turn next to the empirical results.

Table III presents the main estimation results. ${ }^{19}$ In all six specifications reported here, the fixed-effect model (FE) is chosen as the Hausman specification test shows that the null hypothesis of the random effect orthogonal to the explanatory variables is rejected at any conventional confidence levels. The test statistics are reported in the table in the row headed by $\chi^{2}$.

\footnotetext{
${ }^{14}$ We also calculated the import share in terms of deflated real values, but the ratio barely differs from the nominal ratio.

${ }^{15}$ The wage is defined as the real average wage calculated as the deflated total wage payment divided by the number of employees. The employment in this paper is measured in terms of the number of employees, not the total man-hours of work. Although it is due to the data limitation in Annual Survey of Manufacturers, this choice does not seems to affect the main conclusion of this paper since Rebick (1999) found that these two measures result in virtually the same estimates in his model of the trade impact on Japanese wage differentials. The material and energy expenses are used as the non-labor costs.

${ }^{16}$ The import price is deflated by aggregate domestic WPI, while the wage is deflated by aggregate CPI.

17 As in Dekle (1998), the income variable, $y$, is omitted since real GDP turned out to be insignificant and appears an incorrect proxy for business cycles in this context.

${ }^{18}$ The dummy identifying two-digit sector is not included since variability within two-digit sector is large.

${ }_{19}$ The instruments for the wage variable are own one-period lag, current and one-period lagged non-labor cost, and current and one-period lagged alternative wages. We choose wages in service sector and in construction sector as the alternative wages. The data for these alternative wages are from Ministry of Labor Statistics. The instrumental variables assigned to the import price are own one-period lag, current and one-period lagged real effective exchange rate of the yen (drawn from IMF-IFS). The instruments for the import share interacted with the import price (first-differenced logarithm) are own one-period lag, one-period lagged non-labor cost, and current and one-period lagged real GDP (drawn from National Account by Economic Planning Agency).
} 
The sign of wage coefficient $\beta$ is significantly negative, as is appropriate in labor demand function, in all specifications using the instrumental variables (IV) (1) to (5). The OLS estimation, which treats wage as exogenous, reported in the column (6), on the other hand, yields a quite different, wrong result, which shows that the wage is positively related to labor demand. This finding of importance of instrumenting the wage variable confirms the previous result by Dekle (1998). The non-labor input cost factors are significant in all specifications. The lagged employment is also strongly significant, suggesting that labor adjustment costs in Japanese manufacturing are substantial. This observation of sluggish labor adjustment due to adjustment costs appears consistent with existing evidence on Japanese employment. All the coefficient estimates of these variables are quite similar and relatively robust to specification changes across (1) to (5).

The coefficient on the import price, $\boldsymbol{\theta}_{\text {, }}$, is significantly positive in all cases. The finding of the significant employment sensitivity to imports contrasts with the results from some previous studies since they reported no discernible effect of imports on Japanese employment (Brunello (1990), for example). ${ }^{20}$ The finding of this paper, together especially with Dekle (1998), cast doubt on conventional wisdom that Japanese employment is isolated from international competition.

The import price interacted with import share, $\theta_{1}$, is statistically significant in no specification except for that shown in column (4), which excludes the import price term without interaction. We will discuss this insignificance problem in the next paragraphs.

This paper further provides richer information by splitting the whole sample period

\footnotetext{
${ }^{20}$ Burgess and Knetter (1998) conclude that Japanese employment is less responsive to the exchange rate changes in the cross-country comparison context. Tachibanaki et al. (1998) found that the total import impact on employment is small. Higuchi (1989) found that the yen appreciation exerts a restraining impact on Japanese wages only for senior/middle-aged workers. Rebick (1999) detected negligible effect of import share on employment and wage differentials in Japan.
} 
based on the phase of business cycle. The impact of imports on employment may differ depending on the period, since our sample period of 1988-95 can be divided into the following two sub-periods: the earlier years of boom with the real estate and stock bubble during the relatively stable exchange rate and the later years of recession after the burst of the bubble and yen appreciation. The sharp contrast between these two sub-periods is obvious, for example, from the figures depicted in Table II. To control this difference within our sample period, we introduce the period dummy, $D$, which takes the value one until 1992 and zero after 1993, defined based on the sign of average employment change. The dummy is interacted with the import price and with the import price term interacted with import share as follows. ${ }^{21}$

$$
\begin{aligned}
& d \ln L_{i t} \\
& =\alpha_{i}+\left(\Theta_{0}+\eta_{0} D\right) d \ln P_{i t}^{m}+\left(\Theta_{1}+\eta_{t} D\right) M S_{i t} d \ln P_{i t}^{m}+\beta d \ln w_{i t}+\lambda d \ln L_{i, t-1} \\
& \quad+\gamma_{0} d \ln c_{i t}+\gamma_{1} d \ln c_{i, t-1}+\varepsilon_{i t}
\end{aligned}
$$

The estimation results with thus defined period dummy are reported in Table IV. As were in the regressions without the dummy, instrumental variables are assigned and FE model is used for estimating the panel data. The estimates of coefficients of explanatory variables not linked with the dummy appear basically robust to this modification.

All the coefficients, especially for the latter sub-period, are precisely estimated. What should be emphasized most in Table IV is the impressive contrast in the employment response across different sub-periods. First, as the coefficients with the period dummy and those

\footnotetext{
${ }^{21}$ Dekle (1998) included the year-specific dummies not interacted with import price, but a similar specifications of the period dummy in our case yielded estimates with wrong sign for the import price.
} 
without it are almost canceled out, both the import price and the interactive term with import share have virtually no impact on employment in the first sub-period, while they are significant for the latter sub-period in all cases reported in the table. Second, the introduction of the period dummy makes the interaction term with import share, which was insignificant in the previous estimation, now significant for the latter sub-period. Hence, the sensitivity of employment to imports increases with the degree of exposure to imports in the industry. Evaluated at the average import share of $11.4 \%$, the implied employment elasticity with respect to import price is around 0.72 to 0.77 for the latter sub-period. The estimates for the latter sub-period also indicate that employment elasticity in an industry with a $27 \%$ import penetration ratio (one standard deviation above the mean) is larger than one, i.e. around 1.2 to 1.7. Consequently, by comparing the estimates shown in two tables, we can interpret that the relatively low elasticity estimate without the period dummy, 0.1-0.2, is a composite of substantially higher elasticity in recent years and nearly zero response in earlier years.

The estimates of employment elasticity with respect to import price obtained in this paper are in a comparable range with previous results, for example, $0.4-1.7$ by Dekle (1998) from a similar model at the Japanese two-digit level. ${ }^{22}$ Yet none of the differences in estimated values should be exaggerated. Considering differences in data employed in each research, we should emphasize that the principal conclusion revealing significant impact of imports on employment is shared and confirmed. ${ }^{23}$

\footnotetext{
${ }^{22}$ Branson and Love (1988) reported employment elasticity for each 2-digit U.S. industry from nearly zero to about 0.65 . Campa and Goldberg (1998) concluded that a ten percent permanent dollar appreciation reduces overtime employment by around 0.46 percent, based on 2-digit U.S. data. Revenga (1992) found the U.S. elasticity estimate of $0.1-0.4$ for the pooled 38 four-digit industries. ${ }^{23}$ If there exists non-negligible employment adjustment across four-digit industries within two-digit sector, we expect lower estimate of employment elasticity at more aggregate levels. The higher estimate by Dekle (1988) at two-digit level seems at odd with this prediction, but four-digit industry's labor share changes within two-digit sector is mostly less than one percent in our sample. Thus, the interpretation attributing the difference in estimates to the difference in aggregation levels does not work here. Alternatively, one can possibly explain the gap by different data used for real
} 
As for the import share, we detect that the employment elasticity increases significantly with the industry import share during the latter sub-period, but the existing evidence on the relation with import share is mixed. For example, Campa and Goldberg (1997) and Dekle (1998) reported no significant effect of import share on employment sensitivity at the two-digit data for the U.S. and for Japan, respectively. ${ }^{24}$ On the other hand, using the four-digit data, Revenga (1992) found that the responsiveness of U.S. employment to import price changes varies positively with the degree of import penetration in the industry. ${ }^{25}$ Although far from the decisive argument, at least in our case, the comparison of Table IV with Table III suggests that significant linkage with industry import share might have been obscured by the insufficient control for the asymmetry in employment response. The strongly positive relation of employment response with the import share in each industry also confirms, in our context, that the simultaneous observation of employment decrease and falling import prices during the same period is not a mere superficial coincidence.

The estimated magnitude of employment elasticity cannot be neglected also in comparison with average employment fluctuation in whole manufacturing in Japan. The estimates in Table IV indicate that import price fall of around three percent, observed during 1992-95, must have reduced labor demand by more than two percent, evaluated at the mean and held other factors constant. Since the actual employment decrease is less than three percent in terms of the average of 390 industries, substantial share of average employment

\footnotetext{
import price series. Dekle (1988) constructed it from weighted-average of foreign prices, while we derived it from WPI.

${ }^{24}$ Rebick (1999) also reported that import share changes have no significant effect on employment changes in Japan, but his conclusion is based on a different approach.

${ }^{25}$ Since all the cited studies concluding insignificant effect of import share are based on two-digit data, the irrelevance of import share might be the artifact of aggregation. The estimates in Table III show, however, that mere disaggregation does not alter the conclusion. Dekle (1998) refers to Japanese regulation and long-term employment practices as the causes isolating the employment adjustment from industry's exposure to imports. We tried the regressions including the dummy for regulated industry, but they perform poorly.
} 
decline can be accounted for by the intensified import competition during the latter sub-period.

Thus, this paper reveals the substantial impact of competitive pressure from imports on Japanese employment, although international effects have often been neglected in Japan amid the financial troubles after the burst of the bubble. Although the asymmetric employment response could be consistent with sunk costs associated with hiring and firing, the exploration of exact causes of this asymmetry is beyond the scope of this paper and should be left for future research.

\section{CONCLUDING REMARKS}

The impact of imports on labor demand in 390 Japanese manufacturing industries has been investigated. By assigning instrumental variables both to wage and to import variables, and by splitting the sample period based on the phase of business cycle, this paper has revealed that Japanese employment is significantly responsive to import price changes and that the employment sensitivity varies positively depending on the industry import share, especially during the period of declining employment after the burst of the bubble with falling import prices.

A brief overview of basic statistics clearly indicates the needs to take account of the considerable variability among industries when we evaluate the employment response to imports. Therefore, compared with previous studies of Japanese data at the two-digit level, this paper, which exploits the recently available four-digit longitudinal data, could be especially marked as a substantial improvement in controlling for industry-specific factors. 


\section{REFERENCES}

Branson, William H. and Love, James P. (1988), U.S. manufacturing and the real exchange rate, in "Misalignment of Exchange Rates: Effects on Trade and Industry” (R.C. Marston, Ed.), pp.241-275.

Brunello, Giorgio (1990), Real exchange rate variability and Japanese industrial employment, J. Japan. Int. Econ. 4, 121-138.

Burgess, Simon M. and Knetter, Michael (1998), An international comparison of employment adjustment to exchange rate fluctuations, Rev. Int. Econ. 6(1), 151-163.

Campa, Jose Manuel and Goldberg, Linda S. (1998), "Employment versus wage adjustment and the U.S. dollar," NBER Working Paper 6749.

Dekle, Robert (1998), The yen and Japanese manufacturing employment, J. Int. Money Finance 17, 785-801.

Feenstra, Robert C. (1996), “U.S. imports, 1972-1994: Data and concordances,” NBER Working Paper 5515.

Higuchi, Yoshio (1989), Japan's changing wage structure: The impact of internal factors and international competition, J. Japan. Int. Econ. 3, 480-499.

Rebick, Marcus E. (1999), Trade and the wage structure in the presence of price differentials in the product market: The Japanese labor market 1965-1990, J. Japan. Int. Econ. 13, 22-43.

Revenga, Ana L. (1992), Exporting jobs? The impact of import competition on employment and wages in U.S. manufacturing, Quart. J. Econ. 107, 255-284. 
Tachibanaki, Toshiaki, Morikawa, Masayuki, and Nishimura, Taro (1998), Economic development in Asian countries, and the effect of trade in Asia on employment and wages in Japan, Asian Econ. J. 12(2), 123-151.

Tomiura, Eiichi and Uchida, Yukio (2001), "The impact of import competition on gross job creation and destruction: A study based on Japanese import-industry data concordance,” Discussion Paper \#01-DOF-36, Research Institute of Economy, Trade and Industry. 
TABLE I

IMPORT SHARE AND VARIABILITY WITHIN 2-DIGIT SECTOR

\begin{tabular}{|l|r|r|r|r|r|r|}
\hline \multicolumn{1}{|c|}{ INDUSTRY } & \multicolumn{1}{l|}{$\begin{array}{l}\text { MS } \\
\text { IN88 }\end{array}$} & 1991 & 1995 & $\begin{array}{l}\text { Within } \\
\text {-sector } \\
\text { St.Dev }\end{array}$ & MAX & MIN \\
\hline ELECTRIC MACHINERY (30) & 3.17 & 4.27 & 7.78 & 5.29 & 22.09 & 0.09 \\
\hline GENERAL MACHINERY (29) & 2.57 & 2.95 & 3.44 & 3.02 & 13.62 & 0.09 \\
\hline FOOD MANUFACTURING (12) & 9.07 & 11.12 & 11.56 & 11.60 & 36.58 & 0.08 \\
\hline TRANSPORT EQUIPMENT (31) & 2.40 & 3.08 & 3.50 & 11.80 & 34.87 & 0.28 \\
\hline METAL PRODUCTS (28) & 1.00 & 1.30 & 1.66 & 6.16 & 26.29 & 0.39 \\
\hline PRINTING \& PUBLISHING (19) & 0.51 & 0.57 & 0.65 & 1.08 & 2.06 & 0.01 \\
\hline PLASTIC PRODUCTS (22) & 1.16 & 1.31 & 1.88 & 1.89 & 6.19 & 0.24 \\
\hline TEXTILE MILL PRODUCTS (15) & 12.01 & 15.01 & 24.70 & 20.07 & 78.63 & 6.61 \\
\hline CHEMICAL PRODUCTS (20) & 7.88 & 8.17 & 8.42 & 16.31 & 91.58 & 0.82 \\
\hline APPAREL \& OTHER FABRICS (14) & 10.84 & 11.62 & 17.15 & 20.46 & 95.42 & 0.50 \\
\hline CERAMIC, STONE \& CLAY (25) & 2.29 & 2.82 & 2.88 & 11.04 & 57.56 & 0.10 \\
\hline PULP \& PAPER (18) & 5.13 & 4.35 & 5.45 & 22.81 & 83.24 & 0.01 \\
\hline IRON \& STEEL (26) & 3.95 & 3.97 & 3.92 & 10.78 & 31.99 & 0.04 \\
\hline LUMBER \& WOOD PRODUCTS (16) & 12.19 & 15.32 & 18.93 & 22.60 & 72.08 & 0.05 \\
\hline MISCELLANEOUS MANUFCT (34) & 13.60 & 14.62 & 16.84 & 17.17 & 51.97 & 0.41 \\
\hline PRECISION INSTRUMENTS (32) & 7.19 & 9.25 & 14.60 & 20.28 & 97.90 & 0.21 \\
\hline FURNITURE \& FIXTURES (17) & 3.63 & 4.84 & 6.70 & 8.62 & 24.69 & 0.70 \\
\hline NONFERROUS METALS (27) & 24.75 & 21.32 & 20.95 & 19.83 & 56.50 & 0.10 \\
\hline RUBBER PRODUCTS (23) & 5.21 & 6.32 & 8.12 & 12.01 & 40.17 & 0.14 \\
\hline BEVERAGE \& TABACCO (13) & 3.01 & 4.72 & 4.68 & 19.00 & 60.40 & 0.04 \\
\hline LEATHR \& FUR PRODUCTS (24) & 14.87 & 20.52 & 30.46 & 22.77 & 84.43 & 14.69 \\
\hline COAL \& OIL PRODUCTS (21) & 14.87 & 13.75 & 10.15 & 12.55 & 32.26 & 0.21 \\
\hline ORDNANCE (33) & 14.00 & 9.58 & 7.34 & ----- & ----- & ----- \\
\hline
\end{tabular}

(NOTE) The import share (MS) is measured in percentage. The standard deviation, maximum and minimum are defined for import share across four-digit industries within each two-digit sector at 1995. The ordnance industry (33) is composed of only one four-digit industry (3311). The number in parentheses following the abbreviated industry name is the two-digit SIC code for corresponding industry. The industries are arrayed in descending order of the number of employees at 1995. 
TABLE II

SUMMARY STATISTICS

\begin{tabular}{|r|c|c|}
\hline & $1988-92$ & $1993-95$ \\
\hline $\begin{array}{r}\text { EMPLOYMENT } \\
\text { AVERAGE }\end{array}$ & 1.3442 & -2.8125 \\
\hline St. DEV & 24.7359 & 15.3695 \\
\hline MAX & 397.0686 & 181.6488 \\
\hline MIN & -46.2277 & -70.4602 \\
\hline $\begin{array}{r}\text { REAL WAGE } \\
\text { AVERAGE }\end{array}$ & 2.1198 & 0.9444 \\
\hline St. DEV & 4.7316 & 4.9321 \\
\hline MAX & 31.1196 & 42.4596 \\
\hline MIN & -21.4884 & -26.5324 \\
\hline $\begin{array}{r}\text { NON-LABOR COSTS } \\
\text { AVERAGE }\end{array}$ & -0.2058 & -0.6383 \\
\hline St. DEV & 6.1131 & 6.0000 \\
\hline MAX & 37.3988 & 37.2249 \\
\hline MIN & -33.2886 & -35.9442 \\
\hline REAL IMPORT PRICE & & \\
AVERAGE & -0.8005 & -3.2354 \\
\hline St. DEV & 7.0867 & 6.8590 \\
\hline MAX & 26.2283 & 29.8366 \\
\hline MIN & -25.3685 & -21.9187 \\
\hline AVERAGE & 10.3987 & 11.4020 \\
\hline St. DEV & 15.1508 & 15.4568 \\
\hline MAX & 97.3937 & 96.2997 \\
\hline MIN & 0.0013 & 0.0057 \\
\hline & & \\
\hline IMPORT SHARE & \\
\hline
\end{tabular}

(NOTE) All the figures in Table II, except the import share, are percent change rates from the previous year, while the import share is in absolute level (\%). Each figure is expressed in terms of average, over the years during the period, of the cross-section unweighted average (standard deviation, maximum, or minimum) of 390 industries in each year. 
TABLE III

ESTIMATION RESULTS (WHOLE PERIOD)

\begin{tabular}{|c|c|c|c|c|c|c|}
\hline $\begin{array}{c}\text { RHS } \\
\text { variables/ } \\
\text { Statistics }\end{array}$ & $(1) \mathrm{IV}$ & $(2) \mathrm{IV}$ & (3) IV & (4) IV & (5) IV & (6) OLS \\
\hline$d \ln L_{t-1}$ & -0.316 & -0.308 & -0.307 & -0.308 & ---- & -0.313 \\
& $(0.022)$ & $(0.022)$ & $(0.022)$ & $(0.022)$ & & $(0.021)$ \\
\hline$d \ln w_{t}$ & -0.236 & -0.291 & -0.304 & -0.243 & -0.089 & 0.402 \\
& $(0.175)$ & $(0.173)$ & $(0.173)$ & $(0.168)$ & $(0.179)$ & $(0.055)$ \\
\hline$d \ln P_{t}^{m}$ & 0.187 & 0.097 & 0.175 & ----- & 0.117 & 0.095 \\
& $(0.083)$ & $(0.084)$ & $(0.065)$ & & $(0.087)$ & $(0.041)$ \\
\hline$M S_{t} d \ln P_{t}^{m}$ & 0.870 & 1.830 & ---- & 2.727 & 1.137 & -0.546 \\
& $(1.200)$ & $(1.235)$ & & $(0.964)$ & $(1.286)$ & $(0.177)$ \\
\hline$d \ln c_{t}$ & ----- & 0.242 & 0.250 & 0.241 & 0.321 & 0.242 \\
& & $(0.043)$ & $(0.043)$ & $(0.043)$ & $(0.045)$ & $(0.043)$ \\
\hline$d \ln c_{t-1}$ & ----- & 0.314 & 0.300 & 0.325 & 0.300 & 0.290 \\
& & $(0.045)$ & $(0.044)$ & $(0.044)$ & $(0.047)$ & $(0.044)$ \\
\hline$R^{2}$ & 0.163 & 0.186 & 0.185 & 0.186 & 0.116 & 0.205 \\
\hline$\chi^{2}$ & 37.085 & 37.374 & 36.771 & 38.544 & 4.2089 & 39.116 \\
\hline
\end{tabular}

\section{(NOTES)}

1. The dependent variable is the first-differenced employment in the logarithm form $\left(d \ln L_{t}\right)$ in all cases. The figures in parentheses are the standard errors. The columns (1) to (5) are the results from the regressions assigning instrumental variables to wage, import price and import share, while the column (6) is from the regression treating these variables as exogenous.

2. All the regressions employ the fixed-effect (FE) model for the longitudinal data. $\chi^{2}$ is the test statistics for the Hausman test of FE vs. RE models. 
TABLE IV

ESTIMATION RESULTS (WITH PERIOD DUMMY)

\begin{tabular}{|c|c|c|c|c|}
\hline $\begin{array}{c}\text { RHS variables/ } \\
\text { Statistic s }\end{array}$ & $(7)$ IV & (8) IV & (9) IV & (10) IV \\
\hline$d \ln L_{t-1}$ & -0.330 & -0.321 & -0.314 & -0.321 \\
& $(0.0218)$ & $(0.022)$ & $(0.022)$ & $(0.022)$ \\
\hline$d \ln w_{t}$ & -0.509 & -0.519 & -0.528 & -0.419 \\
& $(0.181)$ & $(0.179)$ & $(0.179)$ & $(0.171)$ \\
\hline$d \ln P_{t}^{m}$ & 0.453 & 0.257 & 0.518 & ---- \\
& $(0.133)$ & $(0.135)$ & $(0.099)$ & \\
\hline$D_{t}^{*} d \ln P_{t}^{m}$ & -0.408 & -0.264 & -0.499 & ----- \\
& $(0.134)$ & $(0.134)$ & $(0.109)$ & \\
\hline$M S_{t} d \ln P_{t}^{m}$ & 2.769 & 4.389 & ----- & 6.322 \\
& $(1.606)$ & $(1.646)$ & & $(1.196)$ \\
\hline$D_{t}^{*} M S_{t} d \ln P_{t}^{m}$ & -2.690 & -3.419 & ----- & -4.833 \\
& $(1.196)$ & $(1.186)$ & & $(0.962)$ \\
\hline$d \ln c_{t}$ & ----- & 0.238 & 0.240 & 0.241 \\
& & $(0.043)$ & $(0.043)$ & $(0.043)$ \\
\hline$d \ln c_{t-1}$ & ----- & 0.301 & 0.278 & 0.320 \\
& & $(0.046)$ & $(0.044)$ & $(0.044)$ \\
\hline$R^{2}$ & 0.175 & 0.196 & 0.193 & 0.194 \\
\hline$\chi^{2}$ & 38.026 & 38.546 & 37.288 & 40.819 \\
\hline
\end{tabular}

(Note) The period dummy, D, takes one until 1992 and zero from 1993. The panel data is estimated by FE model with instrumental variables in all cases. The notes to Table III apply to this table. 